\title{
MAB または女性ホルモン剂併用による初期内分泌療法にても PSA 低下が不充分な前立腺癌症例の検討
}

\author{
足利赤十字病院泌尿器科 \\ 中田誠司古谷洋介蓮見勝 \\ 中野 勝也 高橋 溥朋
}

\section{A CLINICAL STUDY ON POOR PSA RESPONSE TO INITIAL ENDOCRINE THERAPY WITH MAB OR ESTROGENIC DRUGS FOR TREATMENT OF PROSTATE CANCER}

\begin{abstract}
Seiji Nakata, Yosuke Furuya, Masaru Hasumi, Katsuya Nakano and Hirotomo Takahashi From the Dept of Urology, Ashikaga Red Cross Hospital
\end{abstract}

(Purpose) The prostate specific antigen (PSA) level usually is lowered in response to initial endocrine therapy even in advanced cases of prostate cancer, but in some cases, it is not. We examined the cases in which the PSA level was not sufficiently lowered by initial endocrine therapy with maximal androgen blockade (MAB) or estrogenic drugs.

(Materials and methods) The subjects were 20 patients with prostate cancer diagnosed between January 1992 and December 2005 whose PSA level was not lowered below $10 \mathrm{ng} / \mathrm{ml}$ after initial endocrine therapy with MAB or estrogenic drugs. We investigated the frequency of cases, pretreatment PSA levels, PSA nadir levels after initial endocrine therapy and throughout the therapy, PSA response to second line therapy, and the prognosis.

(Results) The PSA level was not lowered below $10 \mathrm{ng} / \mathrm{ml}$ after initial endocrine therapy with MAB or estrogenic drugs in $4.9 \%$ of the cases. Cancer-specific survival rates in all cases were extremely poor, $75.0 \%$ at 1 year and $14.7 \%$ at 3 years. Prognosis tended to be worse in patients with a higher PSA nadir level throughout the therapy and on whom second therapy was not effective, although the difference was not statistically significant.

(Conclusion) The patients whose PSA levels were not lowered sufficiently by MAB or estrogenic drugs had an extremely poor prognosis. These results are useful in planning the therapy, and in explaining the status or future prospective of the disease to patients and their families.

Key words : Prostate cancer, endocrine therapy, PSA

要旨：(目的）前立腺癌は, たとえ進行癌であってもほとんどの例で初期内分泌療法に反応して, PSA は一旦低下する. しかし, 初期内分泌療法に対する反応が不良の前立腺癌は, まれだが存在する. 今回, MAB または女性ホルモン剤併用による初期内分泌療法にても PSA の低下が不充分な例について検討 した.

(対象と方法) 対象は，1992 年 1 月から 2005 年 12 月までの間に当院で診断された前立腺癌のうち, MAB または女性ホルモン剤併用による初期内分泌療法にても PSA が $10 \mathrm{ng} / \mathrm{ml}$ 以下に低下しなかった 20 例である.これらについて, その頻度, 治療前 PSA 值, 初期内分泌療法後および全経過中の PSA na$\operatorname{dir}$ 值, 二次治療に対する PSA 反応について調查し, 予後との関係を検討した.

(結果) MAB または女性ホルモン剂併用による初期内分泌療法にても PSA が 10ng/ml 以下に低下し なかった前立腺癌の割合は， $4.9 \%$ であった。それらの癌特異生存率は， 1 年 $75.0 \%, 3$ 年 $14.7 \%$ ときわ めて不良であった．また，全経過中の PSA nadir 值が高い群，二次治療が無効であった群の予後は，そ 
うでない群に比べて有意差はなかったが悪い傾向であった.

（結論）MAB または女性ホルモン剂併用による初期内分泌療法にても PSA の低下が不充分な例の予 後は, きわめて不良であった.この結果は, その後の治療計画立案, 本人・家族に病状や今後の見通し を説明する上で有用である。

キーワード : 前立腺癌, 内分泌療法, PSA

\section{緒 言}

前立腺癌は, 欧米に多くアジアでは少ない(1)が, 近年 日本でも急激に増加している2．以前は遠隔転移を有 する進行例が多かったが，一般大衆への知識の普及, 前立腺特異抗原 (prostate specific antigen：PSA)の普 及や診断技術の向上などで早期に見つかるようになっ てきだ).PSA は腫瘍マーカーの中でも最も優れてい ると言われており 癌も，高頻度で診断されるようになった。一般的に, 前立腺癌は進行癌であっても初期内分泌療法に対する 反応は良好で，ほとんどの例で一旦 PSA は低下する. しかし，初期内分泌療法に対する反応が不良の例もま れに存在する.今回, Maximal androgen blockade （MAB）または女性ホルモン剤併用による初期内分泌 療法にても PSA の低下が充分でない症例について検 討した。

\section{対象と方法}

対象は, 1992 年 1 月〜 2005 年 12 月の間に当院で未 治療の状態で診断された前立腺癌のうち，MAB また は女性ホルモン剂併用による初期内分泌療法にても $\mathrm{PSA}$ が $10 \mathrm{ng} / \mathrm{ml}$ 以下に低下しなかった 20 例である. 内科的あるいは外科的去勢のみでは PSA が $10 \mathrm{ng} / \mathrm{ml}$ 以下に低下せず，後に抗アンドロゲン剤を追加したら 低下した例は除外した. 診断時年齢は 55〜92 歳まで分
布し, 平均 $75.6 \pm 9.4$ (S.D.) 歳, 中央值 76.5 歳であっ た。臨床病期は, B 1 例 $(5.0 \%), \mathrm{C} 1$ 例 $(5.0 \%), \mathrm{D}$ 18 例 $(90.0 \%)$, 分化度は, 高分化 3 例 (15.0\%), 中分 化 10 例（50.0\%），低分化 7 例（35.0\%）であった。初 期内分泌療法の内容は，表 1 の通りである。これらに つき, その頻度, 治療前 PSA 值, 初期内分泌療法後の PSA nadir 值, 全経過中の PSA nadir 值, 二次治療に対 する PSA 反応について調査し, 予後との関係について 検討した．PSA 測定に用いたキットは，PSA キット “栄研”, デルフィアPSA, Tandem-R PSA, ケミルミ ACS-ePSA の 4 種であるが, Tandem-R の值に変換5) して検討した，診断後の予後は Kaplan-Meier 法を用 いて算出し，有意差検定は Logrank 法により行った.

\section{1. 頻度}

\section{結果}

1992 年 1 月〜 2005 年 12 月までの間に, 治療前 PSA 值が $10 \mathrm{ng} / \mathrm{ml}$ 以上で初期治療として内分泌療法を含 む治療が行われたものは 406 例であった，よって，そ の中で MAB または女性ホルモン剂併用による初期内 分泌療法にても PSA が $10 \mathrm{ng} / \mathrm{ml}$ 以下に低下しなかっ た前立腺癌の割合は $4.9 \%$ であった。

2. 治療前後の PSA 值

治療前 PSA 值と, 初期内分泌療法後抒よび全経過中 の PSA nadir 值を表 2 に示す。初期内分泌療法後㧍よ

表 1 初期内分泌療法の内容

\begin{tabular}{ll}
\hline LHRH-A ※1/精巣摘除術 +抗アンドロゲン剂 & $9(45.0 \%)$ \\
LHRH-A/ 精巣摘除術 + DES-P ※2 & $7(35.0 \%)$ \\
LHRH-A/ 精巣摘除術+抗アンドロゲン剂+ DES-P & $3(15.0 \%)$ \\
DES-P + リン酸エストラムスチン & $1(5.0 \%)$ \\
\hline$※ 1:$ LHRH アゴニスト，※2: リン酸ジエチルスチルベストロール
\end{tabular}

表 2 治療前後の PSA 值

\begin{tabular}{l|c|c|c}
\hline & 範囲 & 平均 \pm S.D. & 中央值 \\
\hline 治療前 PSA 值 $(\mathrm{ng} / \mathrm{ml})$ & $52.4 \sim 4,510.4$ & $1,210.7 \pm 1,282.3$ & 772.0 \\
初期内分泌療法後の PSA nadir 值 $(\mathrm{ng} / \mathrm{ml})$ & $11.3 \sim 1,453.5$ & $176.9 \pm 360.8$ & 47.8 \\
全経過中の PSA nadir 值 $(\mathrm{ng} / \mathrm{ml})$ & $1.7 \sim 1,453.5$ & $162.3 \pm 365.8$ & 38.4 \\
\hline
\end{tabular}


図 1 全症例の癌特異生存率.

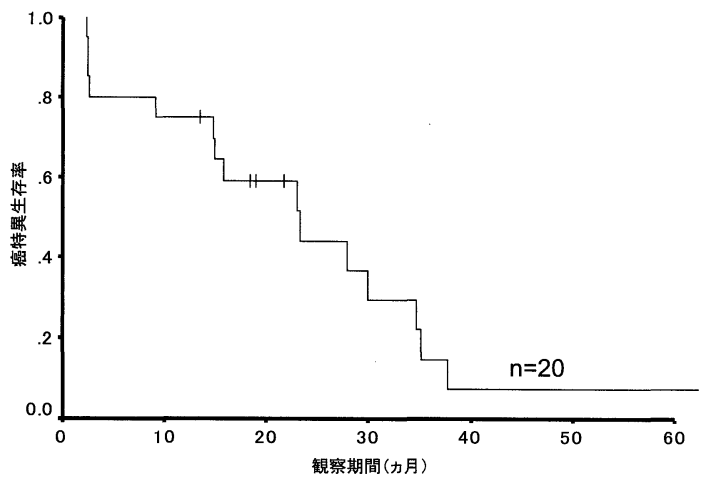

図 2 全経過中の PSA nadir 值別の癌特異生存率.

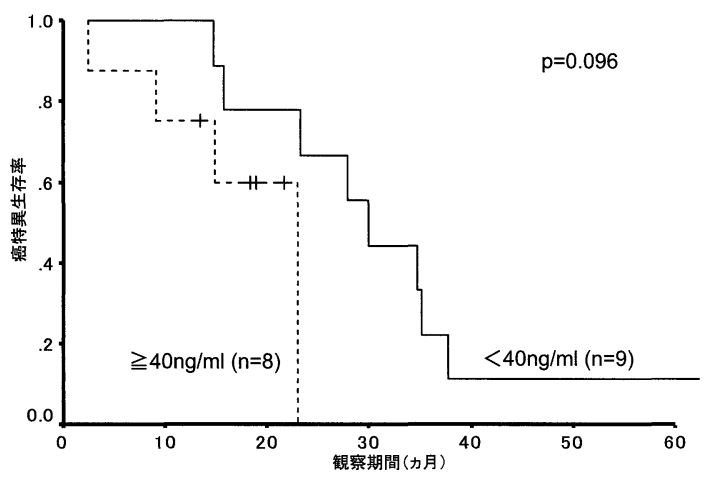

び全経過中の PSA nadir 值は, PSA が低下途中に癌死 した 3 例を除く 17 例について検討した. 治療前 PSA 值は, 中央值 $772.0 \mathrm{ng} / \mathrm{ml}$ と高值であった. 初期内分泌 療法後抒よび全経過中の PSA nadir 值も, 中央值はそ れぞれ $47.8 \mathrm{ng} / \mathrm{ml}, 38.4 \mathrm{ng} / \mathrm{ml}$ と高く, 二次以降の治療 により PSA が $4 \mathrm{ng} / \mathrm{ml}$ 以下に低下したのは 17 例中 2 例のみ（11.8\%）であった.

\section{3. 二次治療に対する PSA 反応}

二次治療を行ったのは，15例であった，内容は，リ ン酸エストラムスチンナトリウム 11 例 $(73.3 \%)$, エチ ニルエストラジオール 3 例 $(20.0 \%)$, 抗癌剤動注 1 例 (6.7\%) であった。二次治療に対する PSA 反応では, 有効（PSA が治療前值より $50 \%$ 以上低下）が 6 例 (40.0\%), 無効 9 例 $(60.0 \%)$ であった.

\section{4. 予後}

全症例の予後を図 1 に示す. 癌特異生存率は, 1 年 $75.0 \%, 3$ 年 $14.7 \%$ と不良であった. 年齢 $(80$ 歳未満と
図 3 二次治療に対する PSA 反応別の癌特異生存率.

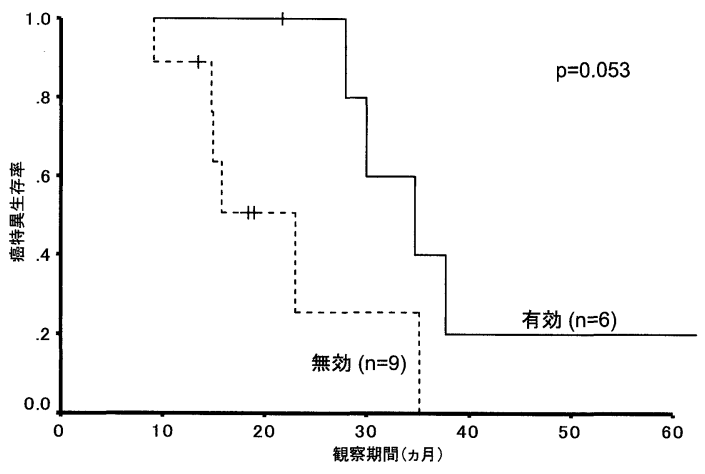

以上), 分化度, 治療前 PSA 值 $(1,000 \mathrm{ng} / \mathrm{ml}$ 未満と以 上), 初期内分泌療法後の PSA nadir 值 ( $40 \mathrm{ng} / \mathrm{ml}$ 未満 と以上), 全経過中の PSA nadir 值 (40ng/ml 未満と以 上), 二次治療に対する PSA 反応別の癌特異生存率で は, 統計学的有意差がでた項目はなかったが, 全経過 中の PSA nadir 值が高い群 $(\mathrm{p}=0.096$, 図 2), 二次治療 が無効であった群（p=0.053, 図 3）の予後が悪い傾向 であった.

\section{考察}

前立腺癌は, 進行癌でも多くは初期内分泌療法に反 応するが,まれに内分泌療法にても PSA が低下しない 例を経験する，そのような例は，早期にホルモン不応 性となり予後不良である. 今回, MAB または女性ホル モン凨併用による初期内分泌療法にても PSA が 10 $\mathrm{ng} / \mathrm{ml}$ 以下に低下しない前立腺癌について, 他のパラ メーターや予後との関係について検討した.

内分泌療法を行った前立腺癌の予後因子として, PSA nadir 值を指摘している報告は数多く見られ $ろ^{6) \sim 9)}$. Furuya $ら^{7)}$ は，内分泌療法を行った転移性前 立腺癌において, PSA nadir 值は PSA 非再燃生存率, 癌特異生存率と相関していたとのべている. また, Kwak ら $^{8}$ は PSA nadir 值が $0.2 \mathrm{ng} / \mathrm{ml}$ 未満の群に比べ て, $0.2 \sim 1 \mathrm{ng} / \mathrm{ml}, 1.1 \sim 10.0 \mathrm{ng} / \mathrm{ml}, 10.1 \mathrm{ng} / \mathrm{ml}$ 以上の群 のホルモン不応性癌への進行のハザード比は, それぞ れ 2.11, 4.13, 4.24 であったとしている. また, 多変量解 析では初回の Hb, ALP 值とともにPSA nadir 值が有 意な生存の予後因子であったとのべている．われわれ の結果でも, 今回検討したPSA nadir 值が $10 \mathrm{ng} / \mathrm{ml}$ 以上の例の予後はきわめて不良であり, PSA nadir 值 が再燃抢よび生存の予後因子であるということは, 間 違いないと考えられる. 
しかし，そのような例の中でも予後の比較的良い群 と悪い群を区別することは可能であろうか. 初期内分 泌療法にても PSA の低下が不充分な例に限っての予 後因子の検討はあまりみられないが, これらはPSA が充分下がりきらないうちに再上昇する例が多いと考 えられ, 再燃前立腺癌の予後因子とほぼ同じではない か考えられる. 再燃前立腺癌の予後因子として最も多 くの報告で指摘されているものは, 再燃時の PSA 倍加 時間 (PSA-DT) である ${ }^{10111}$. Akimoto $~^{10}$ は, 再燃前 立腺癌において再燃後の予後に有意に影響を与えた因 子は, 多変量解析では Performance Status（PS）と PSA-DT（またはPAP-DT）のみであったとのべてい る.また, 堀口ら ${ }^{11} は$ は, さまざまな臨床的パラメーター の中で, 有意に再燃後の予後に影響を与えたのは PSA-DTのみであったとしている.

再燃後二次治療を開始した後の PSA の反応も, 再燃 後の予後因子として注目されている. Kelly $ら^{12)}$ は, ホ ルモン不応性前立腺癌において, 多変量解析では再燃 後の予後に影響を与えた因子は, 二次治療後の PSA $50 \%$ 以上の低下 (予後良好) と LDH であったとのべて いる. Morioka ら ${ }^{13)}$ は, 少量のデキサメサゾンを用いて 治療したホルモン不応性前立腺癌において, PSAが $50 \%$ 以上低下した群はそうでない群に比べて有意に 予後が良かったとしている.

今回は対象が再燃前立腺癌ではなく, 必ずしもすべ ての例で初期内分泌療法後に一旦低下したPSA が再 上昇しているわけではないので, PSA-DT や再燃まで の期間は検討していない. 全経過中の PSA nadir 值と 二次治療に対する PSA の反応が予後と相関する傾向 があったが, 二次治療後の PSA の反応が再燃前立腺癌 の予後因子であるという事実と一致する. 全経過中の PSA nadir 值が高い例や二次治療に対するPSAの反 応が悪い例は, 癌の悪性度が高く予後が悪いのかもし れないが, PSA が下降するような二次治療を行えば予 後が改善される可能性はある.このような例には, 夕 キサン系抗癌剂等の化学療法 ${ }^{14)}$ 視野に入れた積極的 な治療が必要と思われる。

\section{文献}

1) Parkin, D.M., Whelan, S.L., Ferlay, J., Teppo, L. and Thomas, D.B. : Age-standardized (world) incidence (per 100,000) and cumulative (0-74) incidence (percent) rates and standard errors, Prostate (C61). In Cancer Incidence in Five Continents Vol. VIII, p633-635, International Agency for Research on Cancer, Lyon, 2002.

2) Marugame, T., Kamo, K., Katanoda, K., Ajiki, W., Sobue, T. and The Japan Cancer Surveillance Research Group : Cancer incidence and incidence rates in Japan in 2000 : estimates based on data from 11 population-based cancer registries. Jpn. J. Clin. Oncol., 36, 668-675, 2006.

3) 中田誠司, 大竹伸明, 久保田裕, 伊藤一人, 鈴木和 浩, 山中英壽, 群馬大学グループ泌尿器腫掦研究 会: 群馬県における前立腺癌の罪患率, 臨床病期, 組織学的分化度の推移. 泌尿紀要, 50, 165-170, 2004.

4) Oesterling, J.E. : Prostate specific antigen : a critical assessment of the most useful tumor marker for adenocarcinoma of the prostate. J. Urol., 145, 907-923, 1991.

5) Kuriyama, M., Akimoto, S., Akaza, H., Arai, Y., Usami, M., Imai, K., Tanaka, Y., Yamazaki, H., Kawada, Y., Koiso, K., Yoshida, O., Kotake, T., Yamanaka, H., Machida, T., Aso, Y. and Shimazaki, J. : Comparison of various assay systems for prostate-specific antigen standardization. Jpn. J. Clin. Oncol., 22, 393-399, 1992.

6) Matzkin, H., Eber, P., Todd, B., Zwang, R. and Soloway, M.S. : Prognostic significance of changes in prostate-specific markers after endocrine treatment of stage D2 prostatic cancer. Cancer, 70 , 2302-2309, 1992.

7) Furuya, Y., Akakura, K., Tobe, T., Ichikawa, T., Igarashi, T. and Ito, H. : Prognostic significance of changes in prostate-specific antigen in patients with metastatic prostate cancer after endocrine treatment. Int. Urol. Nephrol., 32, 659-663, 2001.

8) Kwak, C., Jeong, S.J., Park, M.S., Lee, E. and Lee, S. E. : Prognostic significance of the nadir prostate specific antigen level after hormone therapy for prostate cancer. J. Urol., 168, 995-1000, 2002.

9）中田誠司, 中野勝也, 高橋溥朋, 清水和彦, 川島清 隆：内分泌療法後にPSA 再燃をきたした前立腺 癌の予後因子. 日泌尿会誌，96,685-690, 2005.

10) Akimoto. S., Inomiya, H., Akakura, K., Shimazaki, J. and Ito, H. : Prognostic factors in patients with prostate cancer refractory to endocrine therapy: Univariate and multivariate analyses including doubling times of prostate-specific antigen and prostatic acid phosphatase. Jpn. J. Clin. Oncol., 27, 258-262, 1997.

11）堀口明男, 畠山直樹, 池内幸一：再燃前立腺癌にお ける前立腺特異抗原の変動と予後. 西日泌尿, 61 , 16-21, 1999.

12) Kelly, W.K., Scher, H.I., Mazumdar, M., Vlamis, V., 
Schwarts, M. and Fossa, S.D. : Prostate-specific antigen as a measure of disease outcome in metastatic hormone-refractory prostate cancer. J. Clin. Oncol., 11, 607-615, 1993.

13) Morioka, M., Kobayashi, T., Furukawa, Y., Jo, Y. Shinkai, M., Matsuki, T., Yamamoto, T. and Tanaka, H. : Prostate-specific antigen levels and prognosis in patients with hormone-refractory prostate cancer treated with low-dose dexamethasone. Urol. Int., 68, 10-15, 2002.

14）白木良一, 桑原勝孝, 櫻井孝彦, 丸山高広, 星長清 隆：ホルモン不応性前立腺癌に対するタキサン系 薬剂の有効性. 泌尿紀要, 52, 481-485, 2006.

(2007 年 1 月 17 日受付, 4 月 11 日受理) 